\title{
WORDSWORTH'S CONCEPT OF POETRY AND POET
}

\section{Naresh Kumar Yadav}

Research Scholar at Faculty of Humanities, Mohan Lal Sukhadia University, Udaipur, Rajasthan, India

Poetry, according to William Wordsworth was a record of "emotion recollected in tranquility", moments of the inspired. Perception produced on emotion, which recollected after some time, revealed its spiritual significance. This view of origin seems unique for no other poet has held such a view, but then few poets have taken us into confidence in this matter. If they had, we might have had a confirmation of Wordsworth's experience which after all, is not so very strange or peculiar as it appears. However, that may be many of his poems were certainly based on. According to Wordsworth, poet would have selected appropriate language, imagination.
\end{abstract}

KEYWORDS: Emotion, Language \& Imagination

Received: Apr 13, 2017; Accepted: May 02, 2017; Published: May 15, 2017; Paper Id.: IJELJUN20174

\section{INTRODUCTION}

The concept of poetic diction and the concept of similarity between the language of prose and poetry are the features of William Wordsworth's poems. He also gives his concept of poetry and poets. In poetry, he gives more importance to the elements of spontaneity, emotion and imagination with whose help; poet recreates the original emotion in his heart that he felt at the time of inspiration.

Wordsworth defines a good poetry as the spontaneous overflow of powerful feelings recollected in tranquility because; the immediate aim of poetry is to give pleasure. According to Wordsworth, the poetic process involves four stages - spontaneous overflow, recollected recreation with the help of imagination and finding appropriate language of imagination to express his idea and feelings. This process can be demonstrated by taking one of the Wordsworth poems" solitary reaper"-

Behold her, single in the field,

Yon solitary highland lass!

Reaping and singing by herself;

Stop here, or gently pass!

Alone she cuts and binds the grain

And sings a melancholy strain:

O listens! For a vale profound

Is overflowing with the sound.

Poet, on a visit or on a walk must have come across a reaper singing girl and working in a valley. This scene must have created some feelings which inspired poets to write about that, but poet might not have his writing 
material facility to record his feelings, so, must have come back to his house and thought about this scene peacefully. Here comes the role of tranquility and imagination with whose help he would have created the same scene and same feelings that he saw and felt while listing to solitary reaper, who was both singing as well as reaping. After creation of the original scene and feelings with the help of imagination poet, he would have selected the appropriate language and phrases to express his feelings as exactly as possible.

This definition of poetry makes Wordsworth poems different from the poetry of neoclassical age, which stressed, since poet meditates to create the same scene or feelings in his heart, it has motivated his poems. Normally, poetry is the breath and finer spirit of all knowledge. It is an impassioned expression, which makes it different from the poetry of the neoclassical age, where more emphasis is given on objectivity rather than impassion or subjectivity. Wordsworth also considered poetry as the first and last of all knowledge, as it is immortal as the heart of man. Wordsworth poetry is near to the heart rather than the head.

Wordsworth chose the simple and rustic life as a subject of poems. So, seeing the simple city of the subject matter, he decided to describe them in the common language of the day, because he believed first of all that there is no difference between the language of prose and poetry accept mature. Secondly, he chose the common language, so as to maintain the element of reality in order to attract the reader. Thirdly, he chose the common language as he wanted to reverse the trend of his age, which gave more stress on language and neglected the content of the poem altogether.

Wordsworth's idea about the poet is the same as the poetry. Since poetry has originated from earth not heaven, so naturally the object of the poet is human beings, although poet is endowed with more lively sensibility more enthusiasm and tenderness, and have greater knowledge of human nature and a more comprehensive soul than a common man. Secondly, a poet celebrates and enjoys the spirit of life more than a common man, and he has acquired a greater redness and power to express what he thinks and feels. He is like a magician, who, with the help of his imagination creates such situations and feelings which are not there and, which are so real that the reader thinks that he also would have thought and acted and felt in the same manner. The poet is chiefly distinguished from other man by a greater promptness to think and feel without immediate external excitement, and a greater power in expressing such thoughts and feelings are produced in him in that manner.

Wordsworth shows the importance of poet by comparing him with a biographer and historian. Since the poet with his imagination can speculate about the future and ideal situations, he has greater freedom and liberty than a biographer and historian. There is only one restriction on the poet, and that is to give immediate pleasure and joy to the reader.

\section{CONCLUSIONS}

Wordsworth, who began as an adherent of the revolution, ended as an extreme conservative. His poem contains nature in the center and that is, his all poems reflects the smell of its. Wordsworth chose the simple events of humble and rustic life as the subject matter of his poem.

\section{REFERNCES}

1. Trivedi, R. D. "A Compendious History of English Literature. Vikash publishing house. 2011. Print.

2. Hudson, W. H. "An outline history of English literature. Maple press.2011

3. Studies in English literature, 1500-1900.vol. 42, no. 4, 2002. Print. 
4. William, Wordsworth. "Preface to Lyrical Ballads. 1802.

5. William j. long. "English literature its history and its significance". 
